in terms of sex ratios. However, we may conclude that plasma from adults may be more procoagulant than that of infants. Our findings may confirm the presence of a regulation mechanism in the coagulation parameters throughout the course of life.

Keywords: Infant, Adult, Microparticle, Thrombin

Anahtar Sözcükler: Süt çocuğu, Erişkin, Mikropartikül, Trombin

Authorship Contributions

Study Conception and Design: Nejat Akar, Filiz Şimşek Orhon; Acquisition and Blood Collection: Filiz Şimşek Orhon, Sevgi Başkan; Laboratory Analysis: Yonca Eğin; Interpretation of Data: Nejat Akar, Filiz Şimşek Orhon; Literature Search: Filiz Şimşek Orhon, Betül Ulukol; Drafting and Writing: Filiz Şimşek Orhon.

Conflict of Interest: The authors of this paper have no conflicts of interest, including specific financial interests, relationships, and/or affiliations relevant to the subject matter or materials included.

Financial Disclosure: This study was supported in part by the Ankara University Research Fund.

\section{References}

1. Chironi GN, Boulanger CM, Simon A, Dignat-George F, Freyssinet JM, Tedgui A. Endothelial microparticles in diseases. Cell Tissue Res 2009;335:143-151.

2. Brummel-Ziedins KE, Everse SJ, Mann KG, Orfeo T. Modeling thrombin generation: plasma composition based approach. J Thromb Thrombolysis 2014;37:32-44.

3. Orhon FS, Egin Y, Ulukol B, Baskan S, Akar N. Evaluation of indirect microparticle activity and parameters of thrombin generation test in healthy infants. Thromb Res 2014;133:281-284.

4. Kenet G, Krumpel A, Nowak-Gottl U. Bleeding issues in neonates, infants and young children. Thromb Res 2009;123(Suppl 2):S35-S37.

5. Karlaftis V, Attard C, Summerhayes R, Monagle $P$, Ignjatovic V. The microparticle-specific procoagulant phospholipid activity changes with age. Int J Lab Hem 2014;36:e41-e43.

6. Castoldi E, Rosing J. Thrombin generation tests. Thromb Res 2011;127(Suppl 3):S21-S25.

7. Butenas $\mathrm{S}$, van't Veer $\mathrm{C}$, Mann KG. "Normal" thrombin generation. Blood 1999;94:2169-2178.

8. Haidl H, Cimenti C, Leschnik B, Zach D, Muntean W. Age-dependency of thrombin generation measured by means of calibrated automated thrombography (CAT). Thromb Haemost 2006;95:772-775.

9. Schneider T, Siegemund T, Siegemund R, Petros $S$. Thrombin generation and rotational thromboelastometry in the healthy adult population. Hamostaseologie 2015;35:181-186.

10. Wu J, Zhao HR, Zhang HY, Ge YL, Qiu S, Zhao J, Song Y, Zhao JZ, Lu SS. Thrombin generation increasing with age and decreasing with use of heparin indicated by calibrated automated thrombogram conducted in Chinese. Biomed Environ Sci 2014;27:378-384.

\title{
Comment: In Response to "Downgraded Lymphoma: B-Chronic Lymphocytic Leukemia in a Known Case of Diffuse Large B-Cell Lymphoma - De Novo Occurrence or Transformation"
}

\author{
Yorum: Cevap Olarak "Geriletilmiş Lenfoma: Diffüz Büyük B-Hücreli Lenfoma Olduğu Bilinen \\ Bir Olguda B-Kronik Lenfositik Lösemi - De Novo Oluşum veya Dönüşüm"
}

Burak Uz, Kadir Acar

Gazi University Faculty of Medicine, Department of Internal Medicine, Division of Adult Hematology, Ankara, Turkey

To the Editor,

We read the letter submitted by Gajendra et al. with deep interest [1]. The authors described a patient diagnosed with diffuse large B-cell lymphoma (DLBCL) non-germinal center B-cell type in 2002 who received 6 cycles of cyclophosphamide, adriamycin, vincristine, and prednisolone (CHOP) followed by radiotherapy. He was well for nearly 5 years, but subsequently his disease locally relapsed. Unfortunately, a planned intensive salvage regimen could not be given because the patient was lost to follow-up. In 2010, despite not being given any treatment modality, he presented with small lymphocytic lymphoma. Finally, 22 months thereafter, he was diagnosed with Rai stage IV chronic lymphocytic leukemia and 6 cycles of fludarabine, 
cyclophosphamide, and rituximab (FCR) were administered, resulting in complete remission.

As is known, indolent or low-tumor-burden lymphomas may transform into aggressive or high-tumor-burden lymphoma forms in a process called "Richter transformation". Although rare, the reverse process may also occur with unknown mechanisms. At this point, there are two main hypotheses that can be suggested: initially, there are two existing malignant clones, and successful eradication of the rapidly proliferating clone with intensive therapy results in the survival of the less rapidly growing clone, which may eventually lead to relapsed disease even many years following the diagnosis [2]; or, less probable, a separate secondary malignant clone that is distinct from the initial clone might appear [3].

Previously, two downgraded lymphoma cases were reported $[2,3]$ after the successful treatment of underlying diffuse non-Hodgkin lymphoma, 3 and 14 years following the initial diagnosis. This well-described patient was accepted as having late-relapsed ( 5 years later) DLBCL, which transformed into a "downgraded lymphoma" without lymphoma-specific therapy. DLBCL patients generally relapse in the first 2 or 3 years following treatment. The largest series of patients with DLBCL who relapsed $\geq 5$ years following diagnosis was reported by a French group [4]; 3.6\% of their cohort had a late relapse and those patients had some distinct clinical features, including localized disease (63\%), favorable International Prognostic Index score (82\%), and extranodal involvement (65\%) at diagnosis. At the time of relapse, $83 \%$ had DLBCL histology, while $17 \%$ had indolent histology. Additionally, having an indolent component at diagnosis (44.4\%) was significantly associated with indolent histology at relapse. However, nearly all the late-relapsed patients with initial good-risk disease were treated adequately with anthracycline-based combined chemotherapy.

Late-relapsed DLBCL patients have poor outcomes; therefore, they must be treated promptly with rituximab plus chemotherapy or (if possible) autologous stem cell transplantation [4]. In the French experience, all late-relapsed patients were heavily treated and the patients experienced their relapse a median of 7.4 years after diagnosis [4]. As an interesting aside, the present patient could not be administered any treatment for 3 years after the confirmation of DLBCL relapse and he presented with downgraded lymphoma. We could not understand why the patient's relapsed high-grade lymphoma resolved without any treatment attempts. Spontaneous remission of DLBCL is exceedingly rare, with only a handful of such cases reported $[5,6,7,8]$. Given the unexplained clinical course of DLBCL in this patient, a probable infectious agent or nonprescription usage of traditional medicinal plants inducing antitumor response by modulating the immune system against lymphomatous cells should be sought in his medical history.

Keywords: Diffuse large B-cell lymphoma, Downgraded lymphoma

Anahtar Sözcükler: Diffüz büyük B-hücreli lenfoma, Geriletilmiş lenfoma

\section{Authorship Contributions}

Concept: Burak Uz; Design: Burak Uz; Data Collection or Processing: Burak Uz, Kadir Acar; Analysis or Interpretation: Burak Uz, Kadir Acar; Literature Search: Burak Uz, Kadir Acar; Writing: Burak Uz.

Conflict of Interest: The authors of this paper have no conflicts of interest, including specific financial interests, relationships, and/or affiliations relevant to the subject matter or materials included.

\section{References}

1. Gajendra S, Jha B, Goel S, Sahni T, Dorwal P, Sachdev R. Downgraded lymphoma: B-chronic lymphocytic leukemia in a known case of diffuse large B-cell lymphoma-de novo occurrence or transformation. Turk J Hematol 2015;32:371-372.

2. Kerrigan DP, Foucar K, Dressler L. High-grade non-Hodgkin lymphoma relapsing as low-grade follicular lymphoma: so-called downgraded lymphoma. Am J Hematol 1989;30:36-41.

3. Ogata $Y$, Setoguchi M, Tahara T, Takahashi M. Downgraded non-Hodgkin's lymphoma in the neck occurring as a secondary malignancy. ORL J Otorhinolaryngol Relat Spec 1998;60:295-300.

4. Larouche JF, Berger $F$, Chassagne-Clement $C$, Efrench $M$, Callet-Bauchu E, Sebban C, Ghesquieres H, Broussais-Guillaumot F, Salles G, Coiffier B. Lymphoma recurrence 5 years or later following diffuse large B-cell lymphoma: clinical characteristics and outcome. J Clin Oncol 2010;28:20942100.

5. Mizuno T, Ishigaki M, Nakajima $K$, Matsue $T$, Fukushima M, Minato $H_{\text {, Nojima }}$

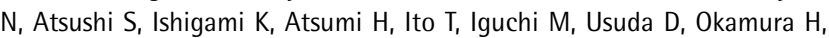
Urashima S, Asano M, Fukuda A, Izumi Y, Takekoshi N, Kanda T. Spontaneous remission of Epstein-Barr virus-positive diffuse large B-cell lymphoma of the elderly. Case Rep Oncol 2013;6:269-274.

6. Buckner TW, Dunphy C, Fedoriw YD, van Deventer HW, Foster MC, Richards KL, Park SI. Complete spontaneous remission of diffuse large B-cell lymphoma of the maxillary sinus after concurrent infections. Clin Lymphoma Myeloma Leuk 2012;12:455-458.

7. Tamás L, Sári $E$, Répássy $G$, Szabó $P$, Bagdi $E$, Krenács $L$, Demeter J. Spontaneous remission in localized diffuse large B-cell lymphoma. Pathol Oncol Res 2011;17:779-784.

8. Watari J, Saitoh $Y$, Fujiya $M$, Nakamura $K$, Inaba $Y$, Okamoto $K$, Tanabe $H$, Yasuda A, Miyokawa N, Kohgo Y. Spontaneous remission of primary diffuse large B-cell gastric lymphoma. J Gastroenterol 2005;40:414-420. 